\title{
The relationship between strategic process dimensions and organisational output performance - A South African investigation in relation to global best practices
}

\author{
H. Oosthuizen \\ University of Stellenbosch Business School, University of Stellenbosch, \\ PO Box 610, Bellville 7535, Republic of South Africa
}

Received May 2005

\begin{abstract}
Strategic management is concerned with the foundations of sustainable superior output performance. In this regard two divergent, but complementary research traditions exist; one is rooted in micro-economics and is commonly referred to as the 'hard' aspects of strategy, whilst the other focuses on social-people aspects, commonly known as the 'soft' aspects of strategy. In emerging countries in Africa, Sub-Saharan Africa and South Africa the soft aspects have been emphasised in research with very little attention afforded to the hard process-behaviour of strategy.
\end{abstract}

This paper contributes to an understanding and assessment of strategic process behaviour in South Africa. It firstly establishes a global best practices framework which provides for different contextual environments. This framework then serves as a benchmark for the empirical findings of a survey amongst South African manufacturing organisations.

The research concludes that South African organisations achieving above-average output performance are those that closely reflect the profile of the global best practices framework. One core dimension of the strategic process, namely Implementation, was statistically found to be significantly related to above-average output performance. Aspects relating to innovative behaviour also displayed a statistical predictive ability towards above-average output performance.

Finally, it is considered that the survey findings suggest an increasingly global context for South Africa and consequently the successful transfer (positive spillover) of strategic management knowledge from the developed to the developing world.

Various research gap-areas were identified and need to be explored.

*To whom all correspondence should be addressed.

\section{Introduction}

Strategic management is concerned with the foundations of sustainable superior output performance. Research in this field primarily originates from two divergent, but complementary traditions. One approach is firmly rooted in micro-economics as a basis for understanding strategy whilst the other focuses on the social or people aspects for the purpose of generating superior strategies and output performance. These two approaches are clearly depicted and combined in the well-known 'hardware' and 'software' elements of the McKinsey 7-S Framework (Peters \& Waterman, 1982:9) whilst Horovitz (1982) devised the terms of respectively 'Intellectual processes' and 'Social processes' for the two research streams. The 'Prescriptive' and 'Descriptive' schools identified by Mintzberg, Ahlstrand and Lampel (1998) provide another possible analogy. For the purposes of this paper the terms 'hard' and 'soft' will be used to denote the two divergent research streams.

Generally speaking there is a dearth of published research findings on strategic management in emerging economies and this is especially true of many countries in Africa (Hoskisson, Eden, Lau \& Wright, 2000:264). What information is available tends to emphasise the importance of the soft strategic issues as they relate to cross-cultural aspects (Jackson, 2004), social-cultural relationships as manifested in leadership, organisational systems, culture, conflict and change management (Blunt \& Jones, 1992), as well as efforts at reconciling indigenous (African) and transplanted (Western) institutional capabilities (Dia, 1996). The same situation holds true for South Africa where strategic management research relates mainly to aspects like social responsibility and management styles (Louw, 2004:254-261) as well as negotiating strategies (Cavusgil, Ghauri \& Agarwal, 2002: 251-256).

It was, however, lamented as early as 1992 that in Africa management training and development of all types will need to give greater attention to the hard issues of 'principles and processes' (author's emphasis) of strategic management (Blunt \& Jones, 1992:68). With the exception of pioneering empirical research (mainly case studies) by Utomi (1998) very little progress seems to have been made in this direction. As far as South Africa is concerned, it was 
established that for the period 1995-2004 (July) no published research exists which may be described as relating to the hard aspects of strategy (USBI, 2004). This is particularly disturbing in view of the finding of the Global Competitiveness Report, 2001-2002 that company operations and strategy in South Africa are less advanced than the absorptive capacity of the business environment.

Against the above background it is the purpose of this paper to contribute to an understanding and assessment of the hard issues, particularly process-behaviour, of strategic management in an emerging economy like South Africa. It is furthermore believed that South Africa constitutes an excellent case study on the transferability and thus the possible developmental spillover benefits of strategic research from the developed world to the developing world, the so-called 'relevancy test'. This is so because of South Africa's historical and cultural roots, size of its economy and pace of internationalisation since 1994.

It is therefore the plan of this paper first to describe the strategic management process against a global 'best practices' framework. See next section, 'A global bestpractices framework'. Secondly, to empirically profile the strategic management process of selected South African organisations and finally, to benchmark and assess whether the South African organisations are consistent with the global best practices framework and also whether these practices can be successfully transferred to an emerging economy like South Africa.

\section{A global-best practices framework}

\section{Introduction}

The strategic process must be viewed against different contextual environments and according to Gilmore and Camillus (1996:869) not enough emphasis is afforded to this type of process thinking in strategic management. Three contextual environments are considered in subsequent sections namely Traditional, Postmodernist and Economic Typology.

The convergence of these environments constitutes, for the purposes of this paper, a framework of global best-practices for the strategic management process. It must be emphasised that there is no intention to participate in the various issues and debates surrounding each one of the contextual perspectives mentioned above, but merely to describe and capture the current state of the literature, i.e. to provide a framework for the empirical research. No critical literature review is intended and the reader is urged to go to the original sources in order to gain a deeper appreciation of the various issues.

\section{Traditional environment}

Strategy formulation, implementation and evaluation are the core dimensions of traditional thinking about the strategic management process. Ehlers and Lazenby (2004:1-15) purports that this is also the way of strategic thinking in Southern Africa. Each one of these dimensions and their break up into sub-dimensions are discussed in the following sections.

\section{Formulation}

Strategy formulation should consider the focus which the organisation will use to generate the strategic input as well as the extent of elasticity to be adopted in response to changing input conditions.

From the 1960's through the 1980's the external environment was the primary focus and thus determinant of strategies organisations selected to be successful - the Positioning Based View (PBV). The late 1980's and 1990's experienced increased external complexity and led to the belief that the organisation's unique internal collection of resources and capabilities should be the focus for strategy the Resource Based View (RBV). The concept of dynamic capabilities, acting as antecedents to reviewing core competencies in a turbulent environment, is an extension of the RBV. However, it remains a 'black box' and consequently unclear precisely what their impact is on strategy formulation and output performance (Protogerou, Caloghirou \& Lioukas, 2005). It is not further explored in this paper. It is increasingly being accepted that together the PBV and the RBV constitute the major underlining effects of the variance in organisational profitability (Priem, 2001:30).

The organisation also needs to contemplate the extent of decision-making elasticity it wishes to pursue in response to charging input conditions, external and/or internal. In this regard alternatives exist on a continuum between formal, incremental and flexible strategy formulation.

The formal approach is a deliberately planned and executed strategy and is conceptually based on March and Simon's (1958) behaviour model of rational decision-making. The incremental approach takes a reactive or adaptive stance (Mintzberg, 1973:46; 1994:114) and is considered to be versatile and emergent. Flexible strategic planning is proactive and innovative in response to change in a highvelocity environment. Innovative thinking is carefully planned (Govindarajan \& Gupta, 2002) and such an approach to formulation provides a clear forward link towards implementation.

\section{Implementation}

The traditional approach to strategy implementation regards it as a separate stage of a rather standardised process. In a worst case scenario it may even be reduced to a broad single project-type policy or directive (Krüger, 2004:206). Although relatively little attention has been afforded to implementation specifically during times of turbulence (Hinterhuber \& Krauthammer, 1998), a radical conceptual shift has taken place to regard implementation as a carefully planned (implementation starts with formulation) change management process, i.e. being people-oriented (De KareSilva, 1997:253). This conceptual shift has emphasised the reality that the overall value of a successful strategy is considered to be more attributable to implementation action, rather than only to the formulation of the strategy itself 
(Waldersee \& Sheather, 1996:105). The caveat, however, being that '... execution means nothing if the strategy (strategy to mean 'formulation', author's note) does not suit the organisation and its environment' (Schendel, 2005:6) and '...effective implementation without deep understanding of strategy ('formulation', author's note) will often depend on luck, impression management, or outright fraud' (Lampel, 2005:20).

\section{Evaluation}

Strategic evaluation is often referred to as 'strategic control'. This term, however, is a paradox because it creates the opposites of past and future performance. The traditional approach to 'strategic control' embraces the relatively easily quantifiable financial and market metrics such as sales targets, market share, ROI and profitability. These metrics, however, are operational in nature and measure the past and current 'wealth' of the organisation, not necessarily its future 'health' (Grundy, 1998). The latter term ('health') is strategic in nature and being better evaluated (rather than controlled) by inter alia the Balanced Scorecard which emphasises building capacity to ensure future competitiveness (Gering \& Kahn, 2000:3), as well as other more contemporary approaches such as Continuous Improvement Programmes. In a turbulent environment, this type of approach also identifies with strategic evaluation as an ongoing dialogue or journey, resulting in evolving strategy formulation, rather than a destination.

\section{Postmodernist environment}

Strategic management is generally acknowledged to be one of the younger sub-disciplines within the broad management context. As such it is typically characterised by challenges to any established way of thinking. Hence, postmodernist thinking in strategy emerged and was necessitated by the turbulence and uncertainty created by the knowledgeeconomy and the changing mental model that society holds of the world. Together these two forces suggest a change in thinking as it pertains to the strategic process.

The connective abilities of today's advances in technology has resulted in developments like value chain deconstruction (Bresser, Hitt, Nixon \& Heuskel, 2000), in turn leading to a blurring of industry boundaries and creating many anomalies regarding industry analysis as well as the configuration of both industry and business value chains. The exponential speed and magnitude of these technological advances has resulted in what earlier writers referred to as 'chaos' (Peters, 1989), 'new age' (Manning, 1988), 'hypercompetition' (D'Aveni, 1994), 'extraordinary management' (Stacey, 1996) and 'crisis' (De Kare-Silva, 1997). Today it is best recognised as Complexity Management (Leibold, Probst \& Gippert, 2002:350).

Until the end of the $19^{\text {th }}$ century societal thinking was dominated by the Newtonian mindset. This view, however, has collapsed and it is increasingly considered that the mental model that society holds of the world has changed to that of an Emerging World View (Dent, 1999). This shift away from reductionism, objective observation, logic and determinism towards holism, perspectival observation, paradox and free-will has had a complicating and social embeddedness impact on strategic thinking, thus exacerbating the move towards the adoption of Complexity Management.

Postmodernist thinking in strategy, as reflected in Complexity Management, can best be directed by an innovative approach as the process model of the future (Ungerer, Pretorius \& Herholdt, 2002:128) and is indeed at the very heart of Blue Ocean Strategy which renders strategic moves termed 'value innovation' whereby rivals are made obsolete (Kim \& Mauborgne, 2004).

\section{Economic typology environment}

It may be reasonable to assume that different economic typologies will be associated with different ways of thinking about the strategic process. However, to arrive at a definitive classification of this nature is extremely difficult and ambiguous, if not impossible. The main reasons being that typologies in both economics and strategy are not necessarily always clearly identifiable, generally recognised or universally accepted. It is furthermore considered that strategic research in emerging markets will of necessity require a flexible approach simply in order to encourage such research (Boyd \& Grove, 2005:254). Notwithstanding the abovementioned uncertainties, an attempt at a representation of the broad relationship between economic typology and the dominant thinking about strategy is suggested below, albeit circumspect and approximate, and is subsequently discussed. See Figure 1.

Entrepreneurial thinking (Covin, 1991) is best suited to economies which are characterised by frequent and unpredictable environmental change, and hence complexity (Blunt \& Jones, 1992:159). These conditions are often associated with economies in transition (moving from a socialist system to a free market economy) (Peng, 2000) and with Lesser Developed Economies (LDC's) in Africa (Utomi, 1998). The levels and traditions of entrepreneurship in Africa are furthermore encouraged by the nature of the Afrocentric culture and tribes (Jackson, 2004:61).

Institutional thinking contends that those organisations achieving strategic fit with the formal as well as informal institutional environments (political, economic, social and educational bodies) will be most likely to achieve relatively higher output performance (Peng, 2000:290). According to Blunt and Jones (1992:37) this situation is very prevalent in LDC's in Africa where managers are often forced to rely on informal network-centered and interpersonal relationships with both public and private sector institutions and officials, thus participating in strategic decision-making. The government, as a major institutional player in LDC's, may be regarded as a 'Sixth Force' in terms of Porter's Five Forces (Austin, 1990:37). 


\begin{tabular}{|l|l|}
\hline \multicolumn{1}{|c|}{ Economic Typology } & \multicolumn{1}{c|}{ Strategic Thinking } \\
\hline Transitional & Institutional \\
\hline Lesser develop countries (LDC's) in Africa & Transactional \\
\hline Developing and Emerging (Africa) & Innovation Driven \\
\hline Developed & PBV and RBV \\
\hline De-industrialised & $\begin{array}{l}\text { Note: It must be emphasised that the dominant strategic way of thinking overlaps. For example, although entrepreneurial } \\
\text { thinking dominates in a transitional economy, it is most certainly also prevalent in de-industrialised economies, both in the } \\
\text { traditional sense as well as in the form of corporate entrepreneurship. }\end{array}$ \\
\hline
\end{tabular}

Figure 1: Relationship between economic typology and strategic thinking

Transactional thinking stems from transaction cost economies (Begg \& Ward, 2003:157-160) and strategic choice is consequently influenced by the organisation's interface with a myriad of exchanges in order to reduce uncertainty and hence the cost of transformation and transactions (North, 1992:28). This is especially true where transaction costs are high due to complexity and uncertainty in the environment, such as in developing and emerging economies (Hoskisson, Eden, Lau \& Wright, 2000:254). In African economies the transaction cost is furthermore heightened by the lack of institutional direction. For example, the inability to enforce contractual agreements (Jackson, 2004:65) as well as 'unstable political and macroeconomic policy climate, weak infrastructure base and unattractive labour cost' (Ibeh, 2005).

Strategic thinking relating to the Positioning Based View (PBV) and the Resource Based View (RBV) is well researched and documented and will not be further espounded upon. These approaches are characteristic of the developed industrialised economies. According to Proff, however, most emerging economies can also benefit by cultivating the PBV (Proff, 2003: 1 \& 4) whilst the RBV is considered to have a limited applicability in these economies (Proff, 2003:5).

Innovation-driven thinking, as it also relates to corporate entrepreneurship (Barringer \& Bluedorn, 1999), appears in highly developed high-income economies which are in the de-industrialisation phase of development. The United States of America, Europe and Japan form The Triad considered to be in this stage of development. This phase is characterised by a dynamic, radically changing environment, particularly in segments like biotechnology and software (Proff, 2003:1). More improvement in quality and efficiency is no longer enough and the ability to produce innovative products and services at the global technology frontier, using the most advanced methods, becomes the dominant source of competitive advantage (Global Competitiveness Report 2001-2002, 2002:Chapter 1.2). Innovation-driven thinking is imperative and manifests itself in practices and processes related to learning and pro-active actions as it relates to people, systems-structures-processes and technology (Ungerer, Pretorius \& Herholdt, 2002:129).
It is considered that innovative strategic thinking can be feasible in an emerging economy should the organisation have already developed lucrative, high-margin markets using traditional cost-leadership or differentiation strategies (Proff, 2003:3).

\section{Empirical research methodoly}

\section{Problem statement}

Major problem

The paucity of information regarding the process-behaviour aspects of strategic management in South Africa and hence whether local strategic applications are consistent with global best practices.

\section{Secondary problem}

Can global best practices successfully be transferred to South Africa?

\section{Research objectives}

Primary objective.

The primary objective of this research is to empirically profile, describe and understand the strategic process behaviour of selected South African organisations.

\section{Secondary objectives}

(i) To compare the strategic management process of selected South African organisations with that of a global best practices framework in order to determine the relevance of applying such benchmarks in the South Africa context.

(ii) To establish which dimensions of process behaviour are the best predictors of superior output performance.

\section{Research hypothesis}

The research hypothesis is the following: Those South African organisations achieving superior output performance will also be those that display a profile consistent with global best practices, thus suggesting that 
those practices can be transferred to the South African context.

\section{Pilot-study 2001}

The research on which this paper is based was preceded by an unpublished pilot study conducted during 2001 which had the following research objective: 'To empirically establish and profile the strategic management characteristics and practices of selected organisations in South Africa'. The findings of the pilot study were accepted as a Work-in-Progress submission and was presented at the $21^{\text {st }}$ Annual International Conference of the Strategic Management Society (Oosthuizen, 2001).

Primary data was collected using a self-administered questionnaire. A convenience sample was used and consisted of a survey of delegates attending various Executive Development Programmes at the Business School of the University of Stellenbosch. Respondents were judgementally selected to represent large and geographically national organisations from various types of industry.

The overall findings of this exploratory pilot study stated that: ' ... generally it appears that a contemporary approach to strategic management practices can, with some degree of success, be pursued by organisations under New Economy conditions of turbulence in a developing country'. More specifically it was established that:

- $\quad$ Some basic principles (theory) as they relate to strategy in mature, developed economies, are indeed suited to a developing economy such as South Africa.

- Clear differences emerged which apparently are indigenous to South Africa and these aspects need to be reconsidered for their contextual applicability to an emerging market.

A follow-up survey was considered to be worthwhile, exploring some issues in more depth and representing more conclusive and predictive research findings. It was conducted during 2003 and constitutes the basis for the paper.

\section{Method}

The survey method of collecting primary data was employed during the period 10 September to 30 October 2003. Details relating to the questionnaire, sample, data processing and analysis as well as caveat, limitations and generaliseability are outlined in the following sections.

\section{Questionnaire}

The measuring instrument consisted of three major parts. First, the successive behavioural dimensions which constitute the strategic process and the ability of each core dimension to contribute to achieving competitive advantage and thus deliver a sustainable above-average output performance. Secondly, 38 questions to establish the characteristics of and thinking about process behaviour. These questions consisted exclusively of 5 Point Likert- scale statements. Thirdly, in order to determine the level of output performance, respondents were asked to rate their organisations in terms of market share and profit relative to major competitors during the past five years. Subjective measures of this nature are commonly employed and previous studies have found a strong correlation between subjective assessments and the objective measurements (Dess \& Robinson, 1984; Pearce, Robbins \& Robinson, 1987).

Of the sample respondents 69 percent indicated achieving above-average profit performance whilst 23 percent and 8 percent respectively indicated the same or below-average profit performance. A high correlation existed between profit performance and market share with 88 percent of above-average respondents also claiming above-average market share.

Respondents were also asked to rate the level of perceived external uncertainty as experienced by their organisations. This divide will enable research to differentiate strategic process practices between organisations with a 'stable' environment and those with a 'turbulent' environment. Of the sample respondents 74 percent indicated that they regard their environments as having a clear future or one with alternate outcomes (stable), whilst 26 percent considered the environment to be uncertain or very uncertain (turbulent).

\section{Sample}

The population for this survey consisted of 5971 mediumlarge manufacturing organisations (United Nations International Standard Industrial Classification 1997 - \#3) in South Africa. The emphasis is on the manufacturing sector because it is a major structural component of the economy and is the sector where international diffusion of management knowledge is most likely to materialise. Names of organisations, key managers responsible for strategy, and their fax numbers were obtained from Introye Corporation (Pty) Ltd., based on their 'Commercial Data Base of South African organisations'. A nationally representative probability sample of 2985 was drawn by the Marketing and Communication Department of the University of Stellenbosch Business School. They also faxed the selfadministered questionnaire, together with a covering letter from the Director of the Business School, to the selected managers/organisation on 10 September 2003. A total of 223 useable responses had been received by end October, 2003 which was considered to be the cut-off date. This constitutes a response rate of 7,6 percent which is considered to be satisfactory. A follow up request yielded two more responses, i.e. a total of 225 . In the remainder of this paper any reference to South African organisations refers to the sample respondents as described in this paragraph.

\section{Data processing and analysis}

The data measurement is typically on the lower measurement scales - ordinal and nominal - and the specific hypothesis will be tested by applying the non-parametric statistical techniques to test either for differences in location between sub-groups or the degree of association between 
organisational output performance and strategic management process practices.

\section{Caveat, limitations and generalisability}

The criteria for classifying respondents into Above and Below-Average-Output Performance are based on operational matrixes, namely profit and market share. In the present-day terminology with an emphasis on sustainability (economic, environment, social) as the desired outcome, this basis for division may be considered by some as being too narrow. Unfortunately, it would appear that as yet no clear and measurable criteria exist to apply the broader measurements with any great degree of scientific confidence. It may, however, be mentioned that one Likertstatement read as follows: 'Indicate the extent to which your organisation measure community and environmental responsibility'. It was found that more Above-Average respondents (46\%) than Below-Average respondents (12\%) indicated that they Agree/Strongly Agree with this statement. This may suggest that some congruence exists between profit/market share and broader community/environmental concerns.

The findings are limited to medium-large manufacturing organisations in South Africa. Acceptable statistical approaches were applied and findings are considered to be reliable for the chosen sample population. However, the research did suggest some convergence with existing research and certain profiles did emerge. As such it may imply that tentative extensions of the findings could be considered, albeit very tenuously. Consequently this research displays characteristics of the coarse-grained approach to strategy research (Harrigan, 1983).

\section{Empirical research results}

The findings of the survey are structured first around the general Overall Findings, and are followed by a profile description of the Dimensions of the Strategic Process. Finally, the Predictive Ability of Process-Dimensions are addressed.

\section{Overall findings}

In strategy formulation the PBV enjoys slightly more support than the RBV whilst the Incremental and Flexible modes of planning are favoured above a more Formal approach. Pro-active planning behaviour in the Flexible mode is important for Above Average Output Performance. It was furthermore confirmed that factors defining proactive innovative behaviour are positively and statistically significant $(\infty=0,05)$ related to Above-Average- Output Performance.

Implementation of strategy was found to be considered the most important core dimension of the strategic management process. It was also the only dimension to reflect a statistically significant $(\infty=0,05)$ predictive ability with regard to Above-Average-Output Performance. This was specifically the case with the Change Management Approach to implementation.

The Traditional Approach (Operational metrics) to the evaluation dimension dominates the Strategic Approach, albeit not with a major discrepancy. The strategic approach was clearly favoured by Above-Average-Output Performance respondents.

\section{Profile description of the dimensions of the strategic process}

A global process best practices framework under different enviornmental modes of thinking was outlined at the outset of this paper. In this regard Table 1 summarises the findings of the survey and, because broad trends are considered, suffice it to present rounded figures.

\section{Core dimensions}

According to Table 1 Implementation is considered by All respondents to be the most important $(50 \%)$ of the three core process dimensions. For Above Average respondents it rates on par $(40 \%)$ with Formulation. Particularly notable, however, is the rather high importance accorded to Implementation by the Below Average respondents, namely 60 percent. However, it also appears from Table 1 that these respondents are probably placing a wrong emphasis on this core dimension due to their extremely high (71\%) adherence to the dated and Traditional approach to implementation. This finding will again be referred to in the next section.

\section{Sub-dimensions}

\section{Formulation}

The focus in strategy formulation is fairly evenly shared by the externally orientated PBV and the internally orientated RBV. The PBV, however, is throughout somewhat more popular, and more so for Above-Average (58\%) then for Below-Average (53\%).

From the Likert-battery it emerged that the PBV is particularly characterised by organisations with well designed information systems as well as those with an ability to disseminate the environmental information throughout the organisation. In the case of the RBV much attention is afforded to analysing strengths and weaknesses and then carefully utilising resource strengths to develop competencies and competitive capabilities. Technological Know-How is considered to be the most important resource, followed by Human Assets. 
Table 1: Dimensions of the strategic management process

\begin{tabular}{|c|c|c|c|c|c|}
\hline \multirow[b]{2}{*}{$\begin{array}{l}\text { Dimensions of Strategic } \\
\text { Management Process }\end{array}$} & \multirow[b]{2}{*}{ All } & \multicolumn{2}{|c|}{ Output performance } & \multicolumn{2}{|c|}{ External uncertainty } \\
\hline & & $\begin{array}{c}\text { Above } \\
\text { average }\end{array}$ & $\begin{array}{c}\text { Below } \\
\text { average }\end{array}$ & Stable & Turbulent \\
\hline $\begin{array}{l}\text { Core dimensions } \\
\text { Formulation } \\
\text { Implementation } \\
\text { Evaluation }\end{array}$ & $\begin{array}{l}30 \\
50 \\
20\end{array}$ & $\begin{array}{l}40 \\
40 \\
20\end{array}$ & $\begin{array}{l}20 \\
60 \\
20\end{array}$ & $\begin{array}{l}30 \\
50 \\
20\end{array}$ & $\begin{array}{l}40 \\
40 \\
20\end{array}$ \\
\hline & \multicolumn{5}{|c|}{$100 \%$} \\
\hline $\begin{array}{l}\text { Sub-dimensions } \\
\text { Formulation } \\
\text { Focus } \\
\text { Positioning Based View (PBV) } \\
\text { Resource Based View (RBV) }\end{array}$ & $\begin{array}{l}58 \\
42\end{array}$ & $\begin{array}{l}58 \\
42\end{array}$ & $\begin{array}{l}53 \\
47\end{array}$ & $\begin{array}{l}61 \\
39\end{array}$ & $\begin{array}{l}57 \\
43\end{array}$ \\
\hline $\begin{array}{l}\text { Elasticity } \\
\text { Formal } \\
\text { Incremental } \\
\text { Flexible } \\
\end{array}$ & $\begin{array}{l}20 \\
50 \\
30\end{array}$ & $\begin{array}{l}19 \\
53 \\
28\end{array}$ & $\begin{array}{l}24 \\
41 \\
35\end{array}$ & $\begin{array}{l}15 \\
42 \\
43\end{array}$ & $\begin{array}{l}22 \\
53 \\
25\end{array}$ \\
\hline $\begin{array}{l}\text { Implementation } \\
\text { Traditional } \\
\text { Change Management } \\
\end{array}$ & $\begin{array}{l}42 \\
58\end{array}$ & $\begin{array}{l}37 \\
63\end{array}$ & $\begin{array}{l}71 \\
29 \\
\end{array}$ & $\begin{array}{l}51 \\
49\end{array}$ & $\begin{array}{l}39 \\
61\end{array}$ \\
\hline $\begin{array}{c}\text { Evaluation } \\
\text { Traditional } \\
\text { Strategic }\end{array}$ & $\begin{array}{l}57 \\
43\end{array}$ & $\begin{array}{l}55 \\
45\end{array}$ & $\begin{array}{l}76 \\
24\end{array}$ & $\begin{array}{l}59 \\
41\end{array}$ & $\begin{array}{l}55 \\
45\end{array}$ \\
\hline & & & $100 \%$ & & \\
\hline
\end{tabular}

The elasticity level of formulation is clearly vested in the Incremental mode, 50 percent for All respondents, and respectively 53 percent for Above-Average and Turbulent. Although the Flexible mode also enjoys considerable support, it appears somewhat (unexpectedly?) high for Below-Average (35\%) and Stable (43\%) respondents. Could it be that the Below-Average group in fact displays a case in point of 'active inertia', i.e. being very adaptable in decision-making but not really making any progress (Sull, 1999)? The relatively high degree of flexibility (43\%) for Stable respondents is somewhat difficult to comprehend. Shades of the Reactor in the Miles and Snow (1978) typology?

The Incremental approach is characterised by an understanding of the realities of the market place and affording the marketing function a major input-role in overall business strategy formulation. These characteristics were particularly true for Above-Average respondents. The most noticeable characteristic of the Flexible approach was that the organisational climate is very supportive of ideageneration and innovative thinking. This characteristic also dominated Above-Average and particularly Turbulent respondents.

\section{Implementation}

The contemporary Change Management approach to implementation is most important to All (58\%), AboveAverage $(63 \%)$ and Turbulent $(61 \%)$ respondents. Very noticeable is the extreme emphasis of the Below-Average respondents towards adhering to the Traditional approach to implementation (71\%).
The Likert-battery reflected that the most outstanding characteristic of the Traditional approach is the fact that formulation and implementation are viewed as two separate activities. This was particularly true for Below-Average respondents. The Change Management approach emphasises the importance of people in implementing strategy and the recognition that 'implementation starts with formulation', i.e. the implementers are given ownership of formulation. These characteristics were particularly true for AboveAverage respondents.

\section{Evaluation}

The Traditional approach to evaluation tends to dominate, outstandingly so for Below-Average respondents (76\%). A Strategic approach is favoured by Above-Average (45\%) and Turbulent (45\%) respondents. According to the Likertbattery this approach is relatively more strongly characterised, particularly for Above-Average respondents, by long-term measurement horizons, awareness of stakeholder perceptions and quality measurements emphasising management and services/products.

\section{Predictive ability of process dimensions}

All core and sub-dimensions of the strategic management process were tested for statistical significance in order to determine whether above their presence will result in aboveaverage output performance using a test for the differences between proportions $(\infty=0,05)$. Only the core dimension of Implementation, specifically the Change Management variable, significantly separated above-average performance from below average performance. 
The Likert-battery in the questionnaire contained a number of statements relating to innovation that could, with one exception, discriminate above-average performance from below-average performance $(\infty=0,05)$ :

Idea generation

Creativity

Approachability of top management to new ideas

System: Screening and evaluating ideas

$-3,45$

Creativity in departments:

Marketing

Production. Service delivery

$-2,00$

HR

R\&D

$-2,77$

Finance

\section{Summary}

This research adopted a mixed methodology design applying both a secondary literature review and empirical (primary) research. The evidence as it emanates from this research is summarised and depicted in Table 2. Findings regarding South African organisations are highlighted $(\sqrt{ })$ and compared to the global best practices framework.

It is clear from Table 2 that those organisations achieving Above-Average-Output Performance are also those that most closely reflect the profile of the global best-practices framework. Particularly important is the statistically significant relationship between above-average output performance and the emphasis placed on implementation (change management approach) over formulation.

Table 2: Comparison of South African organisations with a global best practices framework

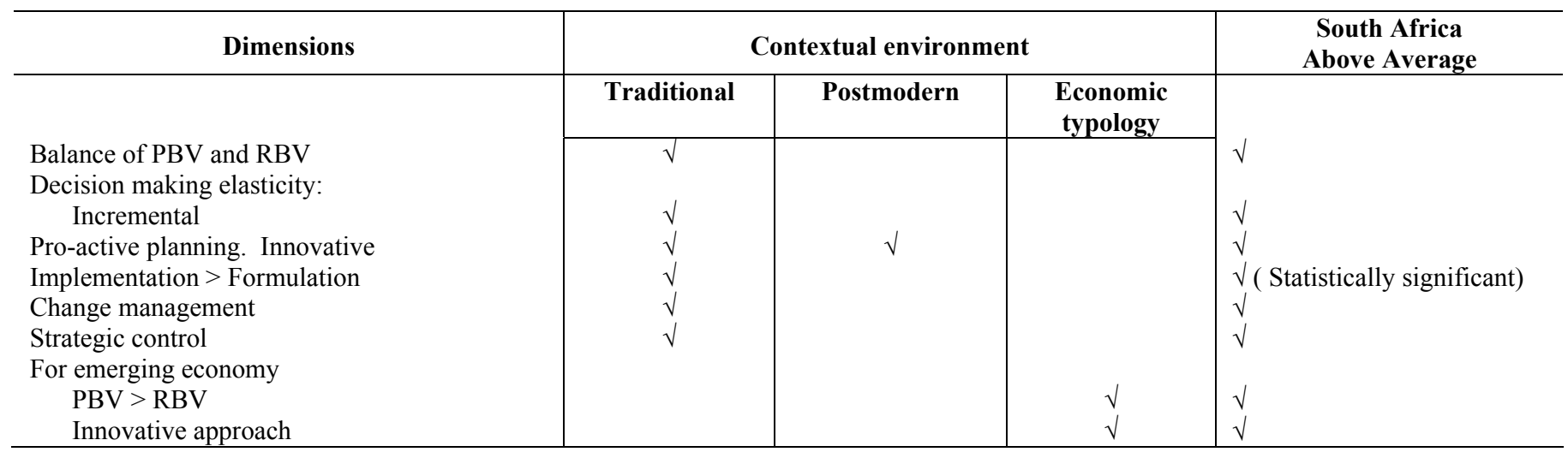

\section{Conclusions and implications}

The 'lesson' to be gleaned from this research, rather than to claim definitive conclusions, is that those South African organisations which achieve above-average-output performance, are also those conforming to a global best practices framework. This appears to suggest that these best practices may be successfully transferred to an emerging country experiencing relatively turbulent environmental conditions. It concurs with a proposition by Summers (1998:2) that: 'The basic steps required in the strategic process apply in any organisation whether that organisation is functioning within an emerging economy, or a welldeveloped and advanced economy'. Shelley (2004:61) too, observes that: 'All the skills and techniques that you need anywhere else will serve you well in Africa'. Unfortunately, however, only scant research information exists on Africa as a whole, and Sub-Saharan-Africa in particular regarding the 'successful' (positive spillover benefits) transfer of this management knowledge (Musonera, Yaprak \& Monplaisir, 2005).

The reasons for the importation and adoption of managerial expertise into an emerging economy may to a large extent be attributed to certain country specific factors (Wood \& Caldas, 2002):
The country becomes increasingly embedded in the world economy and thus management norms and standards acceptable to the global business community. Particularly MNC's increasingly attempt to transfer and leverage their management practices to developing countries in order to achieve rational global coordination and subsequently improve their competitive advantage (Euro-Asia Management Studies Association, 2005).

The management practices historically enforced by colonizers over indigenous ethnic groups.

Drivers of the global model via diffusion agents like large international companies, government use of foreign consultants, presence of international consulting firms, visits and summaries by high profile international strategic management consultants (e.g. Michael Porter and Tom Peters), dissemination of global management practices by local business schools and reproduction of international practices by the media.

These factors have been termed managerial 'antropophagous' and is considered to be 'a management practice which aims to ensure the appropriate adoption, i.e. thoroughly suited to local singularities, of foreign managerial expertise by organisations in emerging countries' (Wood \& Caldas, 2002:11). 
The implication of the above conclusions is that it may be deduced that South African organisations have the capacity to (i) maintain and improve strategic competitiveness in the international markets, and (ii) successfully defend local markets against foreign competitors.

\section{Recommendations}

This research explored the 'hard' process expects of strategic management in South Africa and concluded that it is in line with a global best practices framework. However, based on available research, there appears to be a tendency amongst South African academia and practitioners to relatively concentrate on the 'soft' aspects. This in itself is certainly not a drawback, provided that it does not hamper and take place at the expense of the hard issues. The field of management training should remember that '.. a constellation of squishy issues - leadership, corporate culture, customer care, knowledge management, talent management, employee empowerment, and the like - has encouraged the making of softball players' (Stalk \& Lackenauer, 2004:2) and that '...a handful of classic strategies are timelessly effective in generating competitive advantage' (Stalk \& Lachenauer, 2004:5).

South African practitioners, wishing to impact on both the local and global markets, must adopt and maintain the generally applicable global best practices with regard to the dimensions and thinking about the strategic management process.

Finally, this research suggests various gap-areas which require further exploration:

The relationship between economic typology and strategic thinking.

The relationship between the transfer of strategic global best practices and the nature and extent of the spillover effect on the economic development of the host country.

The lack of hard research in LDC/s in general, and Africa, Sub-Saharan-Africa and South Africa in particular. 'Africa is the neglected continent in terms of international business research' (Newa \& Fillippaios, 2005).

The need to express above-average output performance not only in operational matrixes, but in particularly strategic terms.

\section{References}

Austin, J.E. 1990. Managing in developing countries. New York: The Free Press.

Barringer, B.R. \& Bluedorn, A.C. 1999. 'The relationship between corporate entrepreneurship and strategic management', Strategic Management Journal, 20:421-444.

Begg, D. \& Ward, D. 2003. Economics for business. London: The McGraw-Hill Company.
Boyd, B.K. \& Grove, S. 2005. 'Construct measurement in strategic management research: Illusion or reality?', Strategic Mangement Journal, 26(3): 239-257.

Bresser, R.K.F., Hitt, M.A., Nixon, R.D. \& Henskel, D. 2000. Winning strategies in a deconstructing world. Chichester: John Wiley \& Sons.

Blunt, P. \& Jones, M.L. 1992. Managing organizations in Africa. Berlin: Walter de Gruyter.

Cavusgil, S.T., Ghauri, P.N. \& Agarwal, M.R. 2002. Doing business in emerging markets. London: Sage Publications.

Covin, J.G. 1991. 'Entrepreneurial versus conservative firms: A comparison of strategies and performance', Journal of Management Studies, 28(5):439-462.

D’Aveni, R.A. 1994. Hypercompetition. New York: The Free Press.

De Kare-Silva, M. 1997. Strategy in crisis. London: Macmillan Press, Ltd.

Dent, E.B. 1999. 'Reconciling complexity science in organizations and Christian spirituality'. [online] URL: http://polaris.umuc.ed. Accessed 17 February 2004.

Dess, G.J. \& Robinson, R.B. 1984. 'Measuring organisational performance in the absence of objective measures: The case of the privately held firm and conglomerate business unit', Strategic Management Journal, 5:265-273.

Dia, M. 1996. Africa's management in the 1990s and beyond: Reconciling indigenous and transplanted institutions. Washington, D.C: World Bank.

Ehlers, M.B. \& Lazenby, J.R.A. 2004. Strategic management: Southern African concepts and cases. Pretoria: Van Schaik Publishers.

Euro-Asia Management Studies Association (EAMSA). 2005. 'The transfer of organizational practices: Enhancing competitiveness in Asia/Pacific-European business' relationships'. Obtained from AIB-L@LIST.MSU.EDU. Accessed 16 May 2005.

Newa, F.O. \& Fillippaios, F. 2005. 'The emergence and evolution of the East African multinational enterprise: Internationalization and organizational strategies'. In Proceedings of the $33^{\text {rd }}$ Annual Conference of the UK Chapter of the Acadamy of International Business (AIB) held at the Business School, University of Bath 8-9 April.

Gering, M. \& Kahn, M. 2000. 'Innovation and learning', Accountancy S.A. [online]URL: http://accountancysa.org.za. Accessed: 23 October 2000.

Gilmore, W.S. \& Camillus, J.C. 1996. 'Do your planning processes meet the reality test?' Long Range Planning, 29(6):869-879. 
Global Competitiveness Report 2001-2002. 2002. 'Building the microeconomic foundations of prosperity: Findings from the Microeconomic Competitiveness Index'. Harvard University: World Economic Forum \& Oxford University Press.

Govindarajan, V. \& Gupta, A.K. 2002. 'Strategic innovation: A conceptual road map.' In Leibold, M., Probst, G. \& Gibbert, M. Strategic management in the knowledge economy. Erlangen: Pulicis Corporate Publishing and Wiley-VCH-Verslag GmbH \& Co KgaA.

Grundy, T. 1998. 'Strategic health and financial performance', Strategic Change, 7:43-54.

Horovitz, J. 1982 'New perspectives on strategic management', Journal of Business Strategy, 4(3):19-33.

Harrigan, K.R. 1983. 'Research methodologies for contingency approaches to business strategy', Academy of Management Review, 8(3):398-405.

Hinterhuber, H.H. \& Krauthammer, E. 1998. 'The leadership wheel: The tasks entrepreneurs and senior executives cannot delegate', Strategic Change, 7(3):149162.

Hoskisson, R.E., Eden, L., Lau, C.M. \& Wright, M. 'Strategy in emerging economies', Academy of Management Journal, 43(3):249-267.

Ibeh, K.I.N. 2005. 'Firm-level internationalization in SubSaharan-Africa: Review and implications'. In Proceedings of the $33^{\text {rd }}$ Annual Conference of the UK Chapter of the Acadamy of International Business (AIB) held at the Business School, University of Bath, 8-9 April.

Jackson, T. 2004. Management and change in Africa: A cross-cultural perspective. London: Routledge.

Kim, W.C. \& Mauborgne, R. 2004. 'Blue Ocean Strategy', Harvard Business Review, October: 76-84.

Krüger, W. 2004. 'Implementation: The core task of change management'. In De Wit, B. \& Meyer, R. Strategy: Process, content, context. North Yorkshire: Thomson Learning.

Lampel, J. 2005. 'New perspectives on teaching strategy', European Business Forum, Spring, 21.

Leibold, M., Probst, G. \& Gippert, M. 2002. Strategic management in the knowledge economy. Erlangen: Pulicis Corporate Publishing and Wiley-VCH-Verslag GmbH \& Co KgaA.

Louw, L. 2004. 'The future of management in Africa'. In Jackson, T. Management and change in Africa: A crosscultural perspective. London: Routledge.

Manning, A.D. 1988. The New Age strategist. Johannesburg: Southern Book Publishers (Pty). Ltd.
March, J.G. \& Simon, H.A. 1958. Organizations. New York: Wiley.

Miles, R.E. \& Snow, C.C. 1978. Organizational strategy, structure and process. New York: McGraw-Hill Book Company.

Mintzberg, H. 1973. 'Strategy making in three modes', California Management Review, 16(2), 44-53.

Mintzberg, H. 1994. 'The fall and rise of strategic planning', Harvard Business Review, January-February:107-114.

Mintzberg, H., Ahlstrand, B. \& Lampel, J. 1998. Strategy safari. London: Prentice Hall.

Musonera, E., Yaprak, A. \& Monplaisir, L. 2005. 'Technology and knowledge spillovers in Sub-Saharan Africa (SSA)'. In Proceedings of the $33^{\text {rd }}$ Annual Conference of the UK Chapter of the Academy of International Business (AIB) held at the Business School, University of Bath, 8-9 April.

North, D.C. 1992. Institutions, Institutional Change and Economic Performance. New York: Cambridge University Press.

Oosthuizen, H. 2001. 'Strategic management practices under conditions of turbulence in a developing country. The South African experience.' Paper read at Strategic Management Society's $21^{\text {st }}$ Conference: Reinventing Strategic Management. The Western St. Francis, San Francisco, California, USA, 20-24 October.

Pearce, J., Robbins, D.C. \& Robinson, R.B. 1987. 'The impact of grand strategy and planning formality on financial performance' Strategic Management Journal, 8(2):125-134.

Peng, M.W. 2000. Business strategies in transition economies. London: Sage Pulibcations, Inc.

Peters, T. 1989. Thriving on chaos. London: Pan Books.

Peters, T.J. \& Waterman, R.H. 1982. In search of excellence. New York: Harper \& Row Publishers, Inc.

Priem, R.L. 2001. 'Tautology in the resource-based view and the implications of externally determined resource value: Further comments', Academy of Management Review, 26(1):57-67.

Proff, H. 2003. 'Limits of resource-based explanations of strategic management in emerging economies'. Paper read at the Strategic Management Society's mini-conference Strategic Management in Emerging Economies-challenging the Conventional Wisdom, Chinese University of Hong Kong, 18-19 December.

Protogerou, A., Caloghirou, Y. \& Lioukas, S. 2005. 'Inside the 'Black Box' of dynamic capabilities: Defining and analysing their linkages to functional competences and firm performance'. Paper read at the DRUID Tenth Anniversary 
Summer Conference 2005 on Dynamics of Industry and Innovation: Organization, Networks and Systems. Copenhagen, Denmark, 27-29 June. [online] URL: www.druid.dk/ocs/viewpaper,php?id=545\&cf=3. Accessed 14 September 2005.

Schendel, D. 2005. 'Redefining strategy', European Business Forum, Spring 21:6.

Shelley, S. 2004. Doing business in Africa. Cape Town: Zebra Press.

Stacey, R.D. 1996. Strategic management and organizational dynamics. $2^{\text {nd }}$ edition. London: Pitman Publishing.

Stalk, G. \& Lackenauer, R. Harvard Business Review. [online] URL: http://web10.epnet.com. Accessed: 7 May, 2004.

Sull, D.H. 1999. 'Why good companies go bad', Harvard Business Review, July-August: 42-52.

Summers, B.I. 1998. 'Strategic process applications to emerging economies', Academy of Management Journal, April, 2:689-713.

Ungerer, M., Pretorius, M. \& Herholdt, J. 2002. Viable business strategies: A systemic, people-centric approach. Randburg: Knowles Publishing.

USBI. University of Stellenbosch Business School. 2004. Four data-bases - SACAT, ISAP, SA-e-Publications and NEXUS.

Utomi, P. 1998. Managing uncertainty - Competition and strategy in emerging economies. Lagos: Spectrum Books Limited.

Waldersee, R. \& Sheather, S. 1996. 'The effects of strategy type on strategy implementation actions', Human Relations, 49(1): 105-122.

Wood, T. \& Caldas, M.P. 2002. Academy of Management Executive, 16(2). [online] URL: http://web8.epnet.com. Accessed 23 June, 2003. 